\title{
RETRACTION
}

The editorial team of the Revista Brasileira de Enfermagem communicates the formal population of Disclaimer for the extraction of the article:

Vieira IFO, Garcia ACM, Brito TRP, Lima RS, Nogueira DA, Rezende EG, et al. Burden and social support among informal caregivers of people on hemodialysis: a mixed study. Rev Bras Enferm. 2021;74(6):e20201266. https://doi.org/10.1590/0034-7167-2020-1266

Since the duplicate publication of the article that was made available in a previous edition of the Revista Brasileira de Enfermagem was proven:

Vieira IFO, Garcia ACM, Brito TRP, Lima RS, Nogueira DA, Rezende EG, et al. Burden and social support among informal caregivers of people on hemodialysis: a mixed study. Rev Bras Enferm. 2021;74(3):e20201266. https://doi.org/10.1590/0034-7167-2020-1266

\section{Dulce Aparecida Barbosa}

Editor in Chief 


\title{
Burden and social support in informal caregivers of people undergoing kidney dialysis: a mixed study
}

\author{
Sobrecarga e apoio social entre cuidadores informais de pessoas em diálise renal: estudo misto \\ Sobrecarga y apoyo social entre cuidadores informales de personas en diálisis renal: estudio misto
}

Ingrid Fernanda de Oliveira Vieira' ORCID: 0000-0001-6171-6852

Ana Cláudia Mesquita Garcia' ORCID: 0000-0001-9793-7905

Tábatta Renata Pereira Brito' ORCID: 0000-0001-9466-2993

Rogério Silva Lima' ORCID: 0000-0002-1751-2913

Denismar Alves Nogueira' ORCID: 0000-0003-2285-8764

Eliane Garcia Rezende' ORCID: 0000-0003-2232-3671

Silvana Maria Coelho Leite Fava' ORCID: 0000-0003-3186-9596

'Universidade Federal de Alfenas. Alfenas, Minas Gerais, Brazil.

How to cite this article: Vieira IFO, Garcia ACM, Brito TRP, Lima RS, Nogueira DA, Rezende EG, et al. Burden and social support among informal caregivers of people on hemodialysis: a mixed study. Rev Bras Enferm. 2021;74(6):e20201266. https://doi.org/10.1590/0034-7167-2020-1266

Corresponding author:

Ingrid Fernanda de Oliveira Vieira E-mail: ingridfoliveira@hotmail.com

EDITOR IN CHIEF: Antonio José de Almeida Filho ASSOCIATE EDITOR: Alexandre Balsanelli
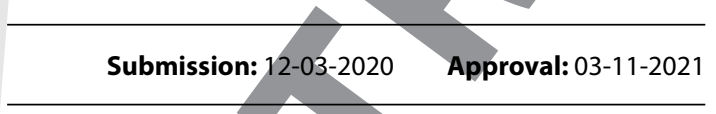

\section{ABSTRACT}

Objectives: to analyze the burden and the social support of the informal caregivers of people undergoing kidney dialysis. Methods: mixed study, based on the Theory of Stress and Overload, using instruments of sociodemographic characterization, the Social Support Survey from the Medical Outcomes Study, Zarit's Burden Scale, and guiding questions. Analysis of data used statistical and thematic inferences. Results: 55 caregivers were evaluated, most were women, from 31 to 50 years old, married, and having worked in care for more than three years. A high level of affective and material support was observed, with a light overload on the caregiver. The central theme of the discourses was: "Experiences of the caregiver: between the burden of responsibility and the search for meaning". Conclusions: a small overload was found in the participants, with a high median in the dimensions of affective and emotional support, in the relations between positive social interactions and the burden of the caregivers, in addition to the duality or responsibility and the meaning of care.

Descriptors: Social Support; Caregivers; Renal Dialysis; Nursing; Renal Insufficiency, Chronic.

\section{RESUMO}

Objetivos: analisar a sobrecarga e o apoio social de cuidadores informais de pessoas em diálise renal. Métodos: estudo misto, fundamentado na Teoria de Estresse e da Sobrecarga, com instrumentos de caracterização sociodemográfica, escala de apoio social do Medical Outcomes Study, Escala de Sobrecarga de Zarit e questões norteadoras. Análise dos dados por inferência estatística e temática. Resultados: avaliaram-se 55 cuidadores, maioria do sexo feminino, idade de 31 a 50 anos, casados e com tempo de dedicação ao cuidado superior a três anos, Observou-se alto nível de apoio afetivo e material e ligeira sobrecarga do cuidador. Construiu-se como tema central dos discursos: "Vivências do cuidador: entre o peso da responsabilidade e a busca por sentido". Conclusões: evidenciou-se ligeira sobrecarga entre os participantes, alta mediana nas dimensões de apoio afetivo e emocional, relação entre interação social positiva e sobrecarga dos cuidadores, além da dualidade entre a responsabilidade e o sentido do cuidar.

Descritores: Apoio Social; Cuidadores; Diálise Renal; Enfermagem; Insuficiência Renal Crônica.

\section{RESUMEN}

Objetivos: analizar sobrecarga y apoyo social de cuidadores informales de personas en diálisis renal. Métodos: estudio misto, fundamentado en Teoría de Estrés y de la Sobrecarga, con instrumentos de caracterización sociodemográfica, escala de apoyo social del Medical Outcomes Study, Escala de Zarit y cuestiones orientadoras. Análisis de datos por inferencia estadística y temática. Resultados: evaluaron 55 cuidadores, mayoría del sexo femenino, edad de 31 a 50 años, casados y con tiempo de dedicación al cuidado superior a tres años. Observado alto nivel de apoyo afectivo y material y ligera sobrecarga del cuidador. Construido como tema central de los discursos:"Experiencias del cuidador: entre el peso de la responsabilidad y la búsqueda por sentido". Conclusiones: evidenciado ligera sobrecarga entre participantes, alta mediana en dimensiones de apoyo afectivo y emocional, relación entre interacción social positiva y sobrecarga de los cuidadores, además de la dualidad entre la responsabilidad y el sentido del cuidar.

Descriptores: Apoyo Social; Cuidadores; Diálisis Renal; Enfermería; Enfermedad Renal Crónica. 


\section{INTRODUCTION}

Chronic kidney disease (CKD) and hemodialysis bring repercussions that impair the diseased person physically, socially, culturally, economically, and spiritually. The complexity of the disease and of its treatment also affect the family and the caregiver. As a result, the caregiver and the health team are important elements of the support network, and contribute to encourage a healthy lifestyle, the maintenance of autonomy and a successful self-care ${ }^{(1)}$.

The informal caregiver is the one who provides non-professional care, receiving no payment for their services ${ }^{(2)}$. Assuming this role is a challenge, since the demands of care have an impact in the economic conditions and change the organization of the activities of the family, requiring strategies to deal with the situation ${ }^{(3)}$. This can have a negative impact, becoming a burden in the life of the caregiver. Social support can be a strategy to relief this burden.

Social support is a system of formal and informal relations through which a person receives emotional, cognitive, and material help to deal with situations that generate stress ${ }^{(4)}$. Studies on burden and social support in informal caregivers are scarce in literature, especially in western society ${ }^{(5)}$, and the same is true for mixed studies in nursing ${ }^{(6)}$. As a result, this investigation is important to strengthen support networks, helping both the diseased and the caregivers to deal with the chronic kidney disease. These networks can help sharing the responsibility of care, leading to benefits in the physical and mental health of the diseased and their caregivers ${ }^{(7-8)}$.

For that to be a reality, it is necessary to carry out studies that analyze the relations between the burden of the caregiver of the person with CKD undergoing hemodialysis and the social support, using methods that improve the experience of the caregiver. Consequently, this work aims to answer the following questions: What is the relation between the burden of the caregivers of people with CKD undergoing hemodialysis and social support? How do caregivers see their roles, the changes in their lives, and their support network in this dynamic?

\section{OBJECTIVES}

To analyze the burden and the social support of the informal caregivers of people with chronic kidney disease undergoing hemodialysis.

\section{METHODS}

\section{Ethical aspects}

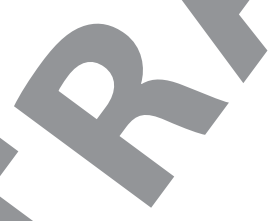

This study was approved by the Ethics Committee for Researches with Human Beings of UNIFALMG, according to Resolution No. 466/12 from the National Council of Health (NCH). To guarantee anonymity, participants were identified using the letter $\mathrm{E}$ followed by a cardinal number, representing the order of the interview.

\section{Study design}

This is a mixed-method, cross-sectional study, following a sequential explanatory strategy. Its first, quantitative (QUANTI) stage, is its priority, while the qualitative (QUALI) stage, which follows, has less weight. The analysis of the data collected in the QUANTI stage directed the data collection of the QUALI stage, based on the references about social support ${ }^{(9)}$ and Burden ${ }^{(10)}$. Data was compared to establish convergences, divergences, and combinations $^{(11)}$. The instruments STROBE (Strengthening the Reporting of Observational Studies in Epidemiology) ${ }^{(12)}$ and COREQ (Consolidated Criteria for Reporting Qualitative Research) ${ }^{(13)}$ were used to guide the methodology.

\section{Participants and place of study}

The study counted on the participation of 55 informal caregivers of people undergoing hemodialysis in the nephrology unit of a philanthropic institution located in a city in the South of Minas Gerais, Brazil. The sample was non-probabilistic, by convenience, made up by all informal caregivers of people who were undergoing renal replacement therapy from August 2018 to March 2019, who accepted participating in the study. The inclusion criteria adopted were: being 18 years old or older; being the informal caregiver of a person undergoing kidney dialysis (from the family or not); and occupying the role of caregiver for at least three months, time needed for them to become familiar with the guidance and with the exercise of care ${ }^{(14)}$. Caregivers who were absent in the renal dialysis session at the time of data collection were excluded.

\section{Collection and organization of data}

After scheduling, data collection was carried out by the main researcher in private with the caregiver. It was the first contact with the participants. Two stages were developed: the first aimed to acquire sociodemographic information and data relative to the burden. It was carried out using a sociodemographic questionnaire, Zarit's Burden Scale, and the Social Support Survey from the Medical Outcomes Study - MOS.

The sociodemographic questionnaire included the following variables: sex, age, marital status, educational level, number of children, religious belief, being or not a relative of the person undergoing hemodialysis, living or not with the person, time providing care, life habits, work activity, and activities of the informal caregiver.

The MOS Social Support Survey was developed to carry out a study with adults who presented chronic pathologies ${ }^{(15)}$. It was validated in Brazil ${ }^{(16)}$ and made up by 19 items, which evaluate 5 functional dimensions of social support: tangible support, affectionate support, emotional support, informational support, and positive social interactions. For each question, the response options were: never (1), rarely (2), sometimes (3), almost always (4), or always (5) - the dimensions of social support are analyzed separately. For each dimension, the scores of each question were summed up, divided by the maximum value of the score of the dimension (15 or 20), and the result was multiplied by 100 . After the score of the transform was found, the median for each dimension of each participant was verified. Values below the median correspond to little social support, while values equal or above the median correspond to much social support ${ }^{(16)}$. 
Zarit's Burden Scale, on the other hand, is an instrument that evaluates the burden of caregivers of diseased people. It is validated in Brazil ${ }^{(17)}$ and formed by 22 items. The analysis is carried out by calculating the score of the instrument. Each item receives a score from 0 to 4, as follows: never (0), rarely (1), sometimes (2), frequently (3), and always (4). The last item in the scale is an exception. It is composed by the question "Overall, how burdened do you feel in caring for $S$ (the person who receives care)?". The answers indicate how much the caregiver feels burdened by their role, as follows: no burden (0), mild (1), moderate (2), severe (3), very severe (4). The analysis classified the burden according to the score, as follows: below or equal to 21 (no burden), 22 to 40 (mild to moderate burden), 41 to 60 (moderate to severe burden), and 61 or more (severe burden) ${ }^{(18)}$.

The interview was chosen as a data collection technique to facilitate the understanding of the patient, and a cone of colors was used as a visual aid, to help participants in responding to Likert questions.

The second stage followed the first immediately. It aimed at receiving the reports of caregivers regarding their roles, experiences, and support network. All 55 participants were invited to participate. However, 25 could not follow it through, since they needed transportation to go back to their cities or were absent in the date of collection. Therefore, 30 people agreed to continue with the recording of the interview.

The semistructured interview technique was used. Interviews were recorded using the voice recorder application of a smart phone and lasted for a mean of 10 minutes. They included the questions: "How do you feel in caring for S? Does anyone help you caring for $S$ ? Other to you, on whom can $S$ count for help? At home, what types of care do you provide to $S$ ? Do you seek any type of help to care for S? Which? In addition to caring for $\mathrm{S}$, what else do you do in your day-to-day life? Do you think $\mathrm{S}$ depends on you? Caring for $\mathrm{S}$ burdens you? By providing care to $\mathrm{S}$, do you consider that no time is left for you? Do you feel tired? If so, what do you do to rest?" Data were transcribed by the main researcher immediately after collection.

\section{Data analysis}

Quantitative data was typed into electronic spreadsheets in the Microsoft Excel software, by double input. Statistical analysis was carried out using the software Statistical Package for the Social Sciences (SPSS 20.0)(19). Sociodemographic data was presented using descriptive statistics. Non-parametric tests were employed due to the evaluation of the hypotheses of parametric tests, found using Shapiro-Wilk's test. Spearman's correlation and Mann-Whitney's were applied to evaluate the association between the final scores of Zarit's Burden Scale and of the dimensions of social support and the sociodemographic variables. The reliability of the instruments used in the study was verified using Cronbach's Alpha(a).

The analysis of qualitative data was carried out by four researchers, in collaboration, and the six stages of the thematic analysis were followed ${ }^{(20)}$. They are: 1) familiarization with the data: interviews were transcribed, read, and data was reread, generating 109 edited pages, and ideas suggested by the data were written down; 2) initial codes were generated: there was a search for words and sentences related to the questions of the research, and the codes were identified by different colors using the tool "Review" in the Microsoft Word software; 3 ) theme elaboration: the codes were organized according to their similarity, considering the Social Support ${ }^{(9)}$ and Burden ${ }^{(10)}$ references; 4 ) review of the themes: the themes and interviews were read once again to analyze the internal homogeneity of the theme and double-check that the different themes were heterogeneous; 5) definition and naming of the themes: a title was attributed to express the content of the interpretation; 6) writing of the report: the article was written, by articulating statements that represented the theme.

\section{RESULTS}

Regarding the sociodemographic characterization of the caregivers, it was found that 41 (74.5\%) were female, 24 (43.7\%) from 31 to 50 years old, 32 (58.2\%) married, 23 (41.8\%) had from one to two children, $32(58.2 \%)$ had only elementary education, $26(47.3 \%)$ had an income from one to two minimum wages, and $38(69.1 \%)$ declared to be catholic.

Life habits of the caregivers: 47 (85.5\%) did not smoke, 40 (72.7\%) did not drinkalcohol, 40 (72.7\%) did not practice physical activities, 30 (54.5\%) did not have leisure activities, 35 (63.6\%) did not have chronic diseases, 31 (56.4\%) From the 24 (43.6\%) caregivers who had a regular job, 12 (50\%) worked up to 20 hours per week.

Kinship: 24 (43.7\%) were children, 28 (50.9\%) did not live with the person they cared for, 28 (50.9\%) had been providing care for three or more years, and 24 (43.7\%) of these provided care from 16 to 24 hours per day. The results regarding the burden and the social support of participants are presented in Table 1.

Table 1 - Scores of Zarit's Burden Scale and medians of the dimensions of the Social Support Survey, Alfenas, Minas Gerais, Brazil, 2019, ( $N=55)$

\begin{tabular}{|c|c|c|}
\hline Burden & $\mathbf{f}$ & $\%$ \\
\hline \multicolumn{3}{|l|}{ Score } \\
\hline No burden & 18 & 32.7 \\
\hline Mild to moderate burden & 26 & 47.3 \\
\hline Moderate to severe burden & 11 & 20 \\
\hline Severe burden & 0 & 0 \\
\hline Social support & \multicolumn{2}{|c|}{ Median } \\
\hline \multicolumn{3}{|l|}{ Size } \\
\hline Tangible & \multicolumn{2}{|c|}{75} \\
\hline Affectionate & \multicolumn{2}{|c|}{100} \\
\hline Emotional & \multicolumn{2}{|c|}{80} \\
\hline Informational & \multicolumn{2}{|c|}{75} \\
\hline Positive social interaction & \multicolumn{2}{|c|}{75} \\
\hline
\end{tabular}

According to Spearman's rho, there was a negative and statistically significant correlation only between the dimensions "Positive social interactions" and "Caregiver burden" ( $r=$ $-0.272 ; p=0.045)$.

Tables 2 and 3 present the sociodemographic characteristics regarding care, according to the overload of the caregiver and the dimensions of social support. 
Table 2 - Sociodemographic characteristics of the caregivers, according to burden, tangible support, affectionate support, positive social interaction, informational support, and emotional support, Alfenas, Minas Gerais, Brazil, 2019

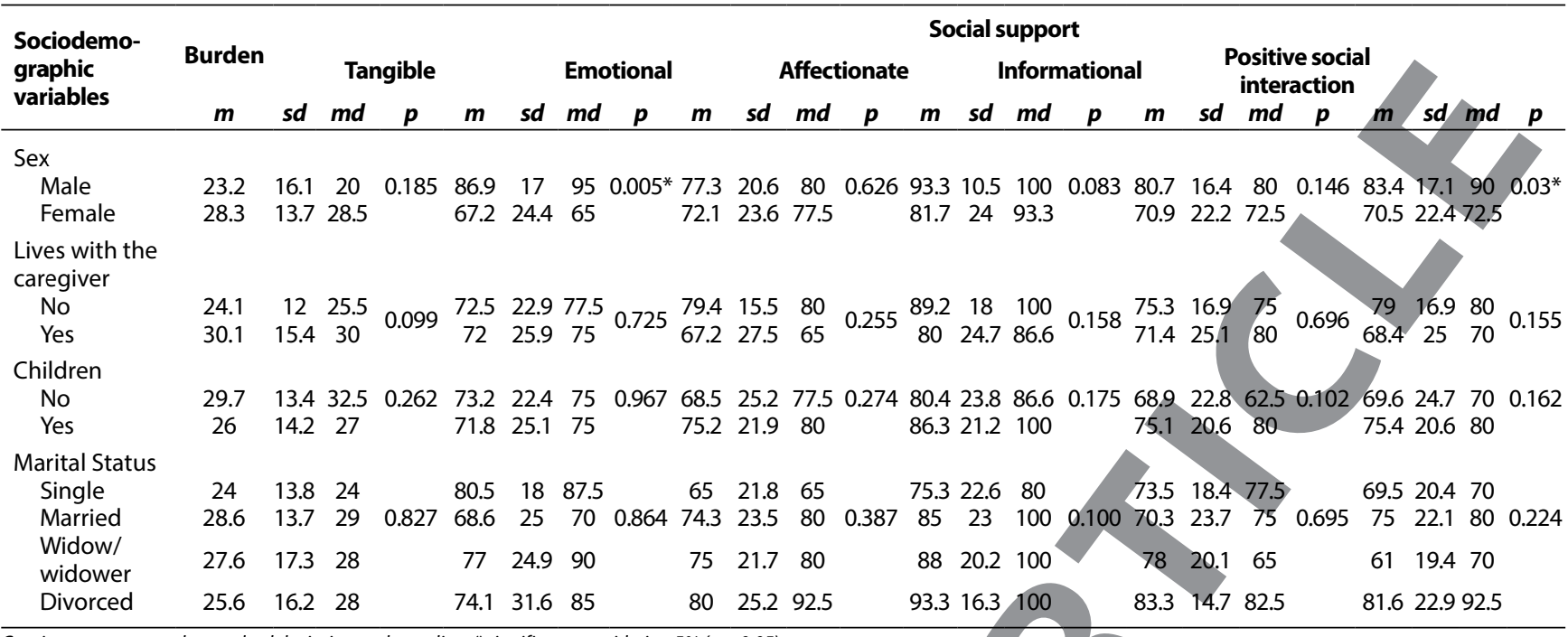

Captions: $m$ - mean; sd - standard deviation; $m d$ - median; * significant considering $5 \%(p \leq 0,05)$.

Table 3 - Association of the burden and social support dimensions with the numerical variables of caregivers of people undergoing hemodialysis, Alfenas, Minas Gerais, Brazil, 2019

\begin{tabular}{|c|c|c|c|c|c|c|c|c|c|c|c|c|}
\hline \multirow[t]{2}{*}{ Variables } & \multirow{2}{*}{$\begin{array}{c}\text { Burden } \\
r\end{array}$} & \multicolumn{2}{|c|}{ Tangible } & \multicolumn{2}{|c|}{ Emotional } & \multicolumn{2}{|c|}{ Affectionate } & \multicolumn{2}{|c|}{ Informational } & \multicolumn{2}{|c|}{$\begin{array}{l}\text { Positive social } \\
\text { interaction }\end{array}$} & \multirow{2}{*}{$p$} \\
\hline & & $p$ & $r$ & $p$ & $r$ & $p$ & $r$ & $p$ & $r$ & $p$ & $r$ & \\
\hline Age & 0.207 & 0.129 & 0.051 & 0.722 & 0.210 & 0.128 & 0.278 & $0.042^{*}$ & 0.161 & 0.242 & 0.040 & 0.770 \\
\hline Time providing care & 0.095 & 0.492 & 0.161 & 0.255 & 0.121 & 0.384 & 0.179 & 0.195 & 0.134 & 0.329 & 0.123 & 0.371 \\
\hline Income & 0.352 & $0.009^{*}$ & 0.076 & 0.598 & 0.147 & 0.293 & -0.021 & 0.882 & 0.026 & 0.851 & 0.022 & 0.876 \\
\hline Years of formal education & -0.079 & 0.567 & -0.052 & 0.713 & -0.141 & 0.309 & -0.440 & $0.001^{*}$ & -0.227 & 0.098 & -0.274 & $0.043^{*}$ \\
\hline Daily hours providing care & -0.069 & 0.755 & -0.070 & 0.756 & 0.60 & 0.792 & 0.117 & 0.596 & -0.075 & 0.733 & 0.189 & 0.388 \\
\hline
\end{tabular}

Captions: $r$-Spearman's correlation; ${ }^{*}$ significant considering $5 \%(p \leq 0,05)$.

Chart 1 - Analysis of qualitative data

\begin{tabular}{|c|c|c|c|}
\hline \multirow{6}{*}{$\begin{array}{l}\text { Theme: } \\
\text { Experiences of } \\
\text { the informal } \\
\text { caregiver of } \\
\text { the person in } \\
\text { hemodialysis: } \\
\text { between the } \\
\text { burden of } \\
\text { responsibility } \\
\text { and the search } \\
\text { for meaning }\end{array}$} & \multirow{6}{*}{$\begin{array}{l}\text { Well [...] it's complicated. Because } \\
\text { something has to be abandoned } \\
\text { [...] It's [...] we don't have all that } \\
\text { time we used to have, you know? } \\
\text { But I say that I'm thankful for } \\
\text { all that happened, because it } \\
\text { brought us together. (E26) } \\
\text { [...] and I'm also a catholic, I } \\
\text { believe in God [...] He could } \\
\text { even be testing me to see how } \\
\text { I'll react. Because if He gave me, } \\
\text { let's say, this cross, it's for me to } \\
\text { bear till my life is over, to prove } \\
\text { I'm capable of seeing it through. } \\
\text { (E9) } \\
\text { [...] in another case, I would take } \\
\text { such a responsibility, butthere's } \\
\text { another point, my heart would } \\
\text { break if Ileft, because there's no } \\
\text { one else [...] but we go on [...] as } \\
\text { far as we can. (E31) }\end{array}$} & \multirow{2}{*}{$\begin{array}{l}\text { Subtheme 1: } \\
\text { The meanings of caring } \\
\text { for the person with CKD in } \\
\text { hemodialysis }\end{array}$} & $\begin{array}{l}\text { [...] oh, I think everyone has the obligation to care for the other } \\
\text { whenever it becomes necessary. (E10) }\end{array}$ \\
\hline & & & $\begin{array}{l}\text { [...] Caring for him has been [...] well [...] learning every day [...] it puts } \\
\text { our patient to the test, you know? (E18) } \\
\text { [...] Oh, I think everyone has the obligation of caring for the other when } \\
\text { they need. Because we come to this world to serve [...] (E10) }\end{array}$ \\
\hline & & \multirow{2}{*}{$\begin{array}{l}\text { Subtheme 2: } \\
\text { The day-to-day of the } \\
\text { caregiver and the duality in } \\
\text { recognizing the burden }\end{array}$} & $\begin{array}{l}{[. . .] \text { Oh }[. . .] \text { it's an effort, we get tired }[. . .] \text { but }[. . .] \text { it's normal, that's being }} \\
\text { human, right? }\end{array}$ \\
\hline & & & $\begin{array}{l}\text { [...] We get a bit tired, but I never told him "Oh, G., I'm tired of taking you } \\
\text { to hemodialysis." (E7) }\end{array}$ \\
\hline & & \multirow[t]{2}{*}{$\begin{array}{l}\text { Subtheme 3: } \\
\text { Successes and failures } \\
\text { in the search for social } \\
\text { support }\end{array}$} & $\begin{array}{l}\text { [...] Well, there's [...] there's always something necessary, right, from } \\
\text { the health unit. There are the girls who come to the house, right? But, } \\
\text { otherwise, it's here or at the doctor and that's it, we only have ourselves } \\
\text { to figure things out. That's how it is. (E21) }\end{array}$ \\
\hline & & & $\begin{array}{l}\text { [...] They prescribe a medication here, and you go to the health unit [...] they } \\
\text { don't have it, in the little drug dispenser there, they don't have it. They can't } \\
\text { wait for 10, } 15 \text { days [...] The SUS [Single Health System] sucks [...] so what } \\
\text { happens is, I have to spend from my pocket, right? Pay for it [...] (E28) }\end{array}$ \\
\hline
\end{tabular}

A positive correlation was found between the burden of the caregiver and their income, and the same was true for affectionate support, and age. There was also a negative correlation between positive social interactions and educational level. Regarding sex, there was a statistically significant difference in the medians between men and women in positive social interactions and tangible support. The highest scores were in responses from men.
The analysis of qualitative data made it possible to elaborate a central theme, called "Experiences of the informal caregiver of the person in hemodialysis: between the burden of responsibility and the search for meaning". It is presented, with its subthemes, in Chart 1.

The elaboration of the central theme and the subthemes made it possible to see that informal caregivers understand care as an activity that requires them to have a lot of responsibility. This 
experience is marked by duality: on one hand, the participants reported that their lives had to change due to the existential restrictions imposed on them by the demands of care; on the other, the meanings attributed to the actions of care - which they call obligations, affection, divine plan, learning, and responsibility - influenced their perception about support and even that of burden. This allowed caregivers to feel unburdened, even when they put into words the multiple activities they carried out or reported the lack of time for leisure and physical activities. This aspect of the qualitative data, which translates their perceptions about care, is related to the findings of Zarit's Burden Scale, which indicated a mild overload. The perception participants had of the social support, on the other hand, was primarily focused on the relations established with people and institutions. These elements showed potential to help in the provision of better care.

A positive perception of personal relations in the social network of participants is connected to the highest scores of support attributed to affectionate support, in the Social Support Survey. Nonetheless, some reports indicate that this type of support is not always there.

\section{DISCUSSION}

The fact that most caregivers are women, spouses, or children of the patients, corroborates the profile found in studies that investigated the overload and other factors associated to the life conditions of the caregivers of people with chronic diseases ${ }^{(21-22)}$.

The profile which indicates married women (58.2\%) with one-totwo children (41.8\%), who do not live with the person being cared for $(50.9 \%)$, is usually associated with the accumulation of tasks that are not attributed to the caregivers. This could lead to the overload of activities and, therefore, to the exposure to multiple factors that contribute for the exhaustion caused by an overload in physical, emotional, and social work ${ }^{(23)}$. However, the burden was found to be mild, as corroborated by the statements of the participants.

A daily workload of care of 8 to 24 hours (61.9\%), and the fact that most people were caregivers from three to five years (50.9\%), are similarities to another study ${ }^{(24)}$ and make it possible to infer that these caregivers have a severe burden of activities. This is a contradiction when compared to the responses given to the Zarit's Burden Scale, considering that those indicated a mild to moderate burden (47.3\%).

Their lives were found to be marked by restrictions, and some of them did not have time to practice physical activities, leisure, to care for themselves or to have jobs, even though $43.7 \%$ were in the age group from 31 to 50 years old, which is considered a productive one. Continuous and long-term care can restrict many aspects of one's life. It can lead to risks to health and reduce the perception of quality of life ${ }^{(23,25)}$, as well as compromise positive social interactions, as another study indicates ${ }^{(26)}$.

Furthermore, the low income of participants can also generate difficulties in the provision of care, as can their low educational level, since these imply little access to the health system and a worse comprehension of information and of the development of care $^{(27)}$. In this aspect, a lot of the caregivers in this study learn to deal with the diseased person through their daily experiences.

The perceptions of the caregivers show that, when a person becomes responsible for the care of someone with CKD that undergoes hemodialysis, their life is radically transformed. However, they also believe that this activity is noble and gives meaning to their new role, enveloping their experiences in positive affection. This aspect may have contributed for the results of Zarit's scale to indicate a mild to moderate burden.

Living with a person with chronic kidney disease in the terminal stage can be costly for the patient and for the caregiver, since it involves activities that lead to fatigue and exhaustion, leading to social, physical, financial, and psychological issues. The same is true for the burden, and these conditions lead to anxiety, depression, and a worsening of the quality of life ${ }^{(23,28)}$.

Furthermore, these demands of care are complex for many reasons, including the fact that they impact both adults and elders, have associated comorbidities, clinical manifestations, and due to the effects of therapy ${ }^{(29)}$, all of which are conditions that compromise wellbeing and the daily life activities ${ }^{(30)}$. This reality requires from the caregiver true dedication to caring, which increases the burden and the need for social support.

However, it has been found that the dynamics of the interaction between the caregiver and the person receiving care are unique, due to their relations with the subjectivity of the people involved. The team must identify the particularities of each caregiver to aid them in overcoming adversities. Although the results of this study indicated the strong social support perceived, participants often mentioned that the support for themselves and for the person cared for is lacking. On average, their social network includes two relatives and two friends. It was noted that religion, spirituality ${ }^{(31)}$, family, other caregivers, and professionals contribute to reduce the overload.

The highest social support scores were attributed to affectionate support, meaning they have someone when they need caring and affection; and to emotional support, since it meant they have someone they love. When the affectionate and emotional dimensions were compared to the others, it was found that the "tangible", "informational", and "positive social interaction" dimensions had lower scores.

Although all scores were above the median in all dimensions, $61.8 \%$ of participants said they receive no help to provide care. It can be inferred that the participants understand help either as something related to financial and material resources, or as the provision of care that comes from other people or institutions ${ }^{(25)}$. This is coupled with a low income, which makes it more difficult to access the material resources to answer the demands of the caregiver and of the person being cared for.

Regarding the relation between the social support dimensions and the burden of the caregiver, it was found that the lowest the perception of the overload, the stronger the positive social interaction of participants $(r=-0.272 ; p=0.045)$. This helps making sense of the fact that the stronger the support network, the lower the perceived burden of the caregiver. This result corroborates the findings of a study ${ }^{(8)}$ which made it clear that when caregivers can count on someone to share their experiences, their perception of social support is improved, and they feel a relief in their burden.

The perception of a strong social support in the affectionate support dimension is directly related to the age. This allows the inference that people have been seeking social interactions, especially in their social networks, using optimized and selective processes to establish relations with others who offer them emotional comfort ${ }^{(26)}$. 
Regarding sex, women showed a lower score of tangible support and of positive social interactions. These findings could be related to the fact that women assume the role of caregivers and, in most cases, carry out the task with no help from other relatives ${ }^{(25)}$. This occupies a great part of their time, making it more difficult for them to have social interactions.

It was found that the income is directly related to the perception of overload $(r=0.352, p=0.009)$. These results oppose those found in a study ${ }^{(21)}$ that suggested that low income leads to more difficulties in the provision of care, leading the burden to be perceived as more severe, since daily life activities and financial freedom can be affected. Although the participants had low income, they feel satisfied in caring and perceive a strong social support, which helps, and diminishes their burden.

The "affectionate support" $(r=-0.440, p=0.001)$ and the "positive social interaction" $(r=-0.274, p=0.043)$ had an inverse relation with the educational level. This result can be understood through the perception of help from relatives, friends, hemodialysis workers, and other caregivers, situations where the exchange of information and the establishment of bonds were effective. A study about burdens, social support networks, and emotional stress of elderly caregivers had similar results, finding that caregivers with low educational levels had a better score in the "social aspect"(26).

\section{Study limitations}

The sample by convenience, the low number of caregivers at the time of data collection, and the non-evaluation of the degree of dependency of the person cared for can be seen as limitations of the study.

\section{Contributions to the Field of Nursing}

The results reiterate the relevance of the nurses from the nephrology services, whose actions must go beyond the conventional strategies used to provide guidance, in order to aid the caregivers of people with CKD. This study showed the importance of the relation between caregiver and care provided, which must be considered in its particularities, providing the caregivers with space to put their needs into words - especially during dialysis, an important interval for caregivers to care for themselves and their tasks, and to share, with the team, the responsibility for the care, in addition to being a moment that favors the promotion if the caregiver's health.

\section{CONCLUSIONS}

A mild to moderate burden was found in the participants, with a high median in the dimensions of emotional support and affectionate support. Furthermore, the following variables showed relations between positive social interactions and burden: sex and tangible support; sex and positive social interaction; age and affectionate support; income and burden; educational level and affectionate support and positive social interaction.

By giving a voice to the participants, this study could access the feelings, experiences and meanings built in the relation between caregivers and the person with CKD, which suggest that there is an ambiguity between assuming the role of the caregiver and being burdened, in addition to the perception of the social support.

With the scarcity of studies with a mixed approach that relate to burden and to the social support of the caregivers of people undergoing hemodialysis, and considering the relevance of this study for the field of nursing, further investigations should be carried out in other realities and with caregivers of people with other chronic conditions, contributing for the advance of science and the improvement of the provision of care.

\section{FUNDING/ACKNOWLEDGMENTS}

We would like to thank the Coordination for Higher Education Personnel Improvement - Brazil (CAPES).

\section{REFERENCES}

1. Xavier BLS, Santos ID, Silva FVC. Promovendo autocuidado em clientes em hemodiálise: aplicação do diagrama de Nola Pender. Rev Pesqui Cuid Fundam. 2017;9(2):545-50. https://doi.org/10.9789/2175-5361.2017.v9i2.545-550

2. Vieira CPDB, Fialho AVDM, Freitas CHAD, Jorge MSB. Práticas do cuidador informal do idoso no domicílio. Rev Bras Enferm. 2011;64(3):570-9. https://doi.org/10.1590/S0034-71672011000300023

3. Arias RM, Carreño MS, Posada LC. Incerteza dos cuidadores familiares na doença de pacientes sob cuidados paliativos e fatores associados. Rev Latino-Am Enfermagem. 2019;27:e3200. https://doi.org/10.1590/1518-8345.3185.3200

4. Caplan G. Support systems and community mental health: Lectures on concept development. Pasadena: Behavioral Publications;1974.

5. Lindt N, Van Berkel $\mathrm{J}$, Mulder BC. Determinants of overburdening among informal careers: a systematic review. BMC Geriatrics. 2020;20 (1):112. https://doi.org/10.1186/s12877-020-01708-3

6. Oliveira JLC, Magalhães AMM, Misuematsuda L. Métodos mistos na pesquisa em enfermagem: possibilidades de aplicação à luz de Creswell. Texto Contexto Enferm. 2018;27(2):e0560017. https://doi.org/10.1590/0104-070720180000560017

7. Oyegbile YO, Brysiewicz P. Family caregiver's experiences of providing care to patients with End-Stage Renal Disease in South-West Nigeria. J Clin Nurs. 2017;26(17-18):2624-32. https://doi.org/10.1111/jocn.13689

8. Yamashita $\mathrm{CH}$, Amendola F, Gaspar JC, Alvarenga MRM, Oliveira MADC. Association between social support and the profiles of family caregivers of patients with disability and dependence. Rev Esc Enferm USP. 2013;9 47(6):1359-66. https://doi.org/10.1590/ S0080-623420130000600016 
9. Cassel J. An epidemiological perspective of psychosocial factors in disease etiology. Am J Public Health [Internet]. 1974 [cited 2021 Jan16];64(11):1040-3. Available from: https://ajph.aphapublications.org/doi/pdf/10.2105/AJPH.64.11.1040

10. Hoenig J, Hamilton MW. The schizophrenic patient in the community and his effect on the household. Int J Soc Psychiatr [Internet]. 1966 [cited 2021 Jan16];12 (3):165-76. Available from: https://journals.sagepub.com/doi/abs/10.1177/002076406601200301?journalCode=ispa

11. Creswell JW, Clark VLC. Designing and conducting mixed methods research. 2a ed. Los Angeles: SAGE Publications; 2011.

12. Malta M, Cardoso LO, Bastos FI, Magnanini MMF, Silva CMFP. Iniciativa STROBE: subsídios para a comunicação de estudos observacionais. Rev Saúde Pública. 2010;44(3):559-65. https://doi.org/10.1590/S0034-89102010000300021

13. Tong YA, Sainsbury P, Craig J. Consolidated criteria for reporting qualitative research (COREQ): a 32-item checklist for interviews and focus groups. Int J Qual Health Care. 2007;19(6):349-57. https://doi.org/10.1093/intghc/mzm042

14. Oliveira BCD, Garanhani ML, Garanhani MR. Caregivers of people with stroke: needs, feelings and guidelines provided. Acta Paul Enferm [Internet]. 2011 [cited 2020 Jan 15];24(1):43-49. Available from: https://www2.unifesp.br/acta/pdf/v24/n1/v24n1a6_en.pdf

15. Sherbourne CD, Stewart AL. The MOS social support survey. Soc Sci Med [Internet]. 1991 [cited 2020 Jan 15];32(6):705-14. Available from: http://hdl.handle.net/1822/17442

16. Griep RH, Chor D, Faerstein E, Werneck GL, Lopes CS. Validade de constructo de escala de apoio social do Medical Outcomes Study adaptada para o português no Estudo Pró-Saúde. Cad saúde Pública [Internet]. 2005 [cited 2020 Jan 15];21:703-14. Available from: https://www. scielosp.org/article/csp/2005.v21n3/703-714/

17. Scazufca M. Brazilian version of the Burden Interview scale for the assessment of burden of care in carers of people with mental illnesses. Rev Bras Psiquiatr. 2002;24(1):12-7. https://doi.org/10.1590/S1516-44462002000100006

18. Santo EARDE, Gaíva MAM, Espinosa MM, Barbosa DA, Belasco AGS. Cuidando da criança com câncer:avaliação da sobrecarga e qualidade de vida dos cuidadores. Rev Latino Am Enfermagem 2011;19(3):1-9. https://doi.org/10.1590/S0104-11692011000300010

19. SPSS IBM. IBM SPSS statistics for Windows, version 20.0. New York: IBM Corp; 2011.

20. Braun V, Clarke V. Reflecting on reflexive thematic analysis. Qual Res Sport Exerc Health. 2019;11(4):589-97. https://doi.org/10.1080/215967 6X.2019.1628806

21. Guerra HS, Almeida NAM, Souza MR, Minamisava R. A sobrecarga do cuidador domiciliar. Rev Bras Promoç Saúde. 2017;30(2):179-86. https:// doi.org/10.5020/18061230.2017.p179

22. Guerrero-Nava JA, Romero-Quecol G, Martínez-Olivares M, Martínez-Martínez RA, Rosas-Reyes SC. Perception of the primary caregiver on nursing interventions in terminally ill patients. Rev Enferm IMSS [Internet]. 2019 [cited 2020 Jan 15];24(2):91-98. Available from: https:// www.medigraphic.com/pdfs/enfermeriaimss/eim-2016/eim162d.pdf

23. Jafari $\mathrm{H}$, Ebrahimi A, Aghaei A, Khatony A. The relationship between care burden and quality of life in caregivers of hemodialysis patients. BMC nephrology. 2018;19(1):321. https://doi.org/10.1186/s12882-018-1120-1

24. Maschio G, Silva AM, Celich KLS, Silva TG, Souza SS, Filho CCS. The family relationships when dealing with a chronic disease: the family caregiver viewpoint. Rev Pesqui: Cuid Fundam [Internet]. 2019 [cited 2020 Jan 15];11(2):470-4. Available from: https://pesquisa.bvsalud.org/ portal/resource/pt/biblio-969966

25. Cruz THD, Girardon-Perlini NMO, Beuter M, Coppetti LDC, Dalmolin A, Piccin C. Apoio social percebido por cuidadores familiares de pacientes renais crônicos em hemodiálise. REME Rev Min Enferm. 2018;22:e-1119. https://doi.org/10.5935/1415-2762.20180054

26. Kobayasi DY, Rodrigues PR, Fhon SJ, Silva LM, Souza AC, Chayamiti CE. Sobrecarga, rede de apoio social e estresse emocional do cuidador do idoso. Av Enferm. 2019;37(2):140-8. https://doi.org/10.15446/av.enferm.v37n2.73044.

27. Jesus ITM, Orlandi AAS, Zazzetta MS. S. Sobrecarga, perfil e cuidado: cuidadores de idosos em vulnerabilidade social. Rev Bras Geriatr Gerontol. 2018;21(2):194-204. https://doi.org/10.1590/1981-22562018021.170155

28. Bardak S, Demir S, Aslan E, Turgutalp K, Celikcan HD, Dolarslan ME, et al. The other side of the coin in renal replacement therapies: the burden on caregivers. Int Urol Nephrol [Internet]. 2019 [cited 2021 Jan 16];51(2):343-9. Available from: https://link.springer.com/ article/10.1007/s1 1255-018-2029-0

29. Ammirati AL. Chronic Kidney Disease. Rev Assoc Med Bras. 2020;66 (Suppl 1):s03-s09. https://doi.org/10.1590/1806-9282.66.s1.3

30. Chhetri SK, Bara R. Caregiver burden among caregivers of patient undergoing hemodialysis in tertiary care center: a descriptive crosssectional study. J Nepal Med Assoc. 2020;58(223):148-52. https://doi.org/10.31729/jnma.4779

31. Rafati F, Mashayekhi F, Dastyar N. Caregiver burden and spiritual well-being in caregivers of hemodialysis patients. J Relig Health. 2020;59(6):3084-96. https://doi.org/10.1007/s10943-019-00939-y 